\title{
Current State of Bacteria Pathogenicity and their Relationship with Host and Environment in Tilapia Oreochromis niloticus
}

\author{
Huicab-Pech ZG' ${ }^{1}$, Landeros-Sánchez C $^{1 *}$, Castañeda-Chávez MR ${ }^{2}$, Lango-Reynoso $\mathrm{F}^{2}$, López-Collado CJ1 and Platas Rosado DE ${ }^{1}$ \\ ${ }^{1}$ Post Graduate College, Campus Veracruz, via Paso De Ovejas, Tepetates, Municipality of Manlius, Veracruz, Mexico \\ ${ }^{2}$ Technological Institute of Boca Del Rio, Division of Graduate Studies and Research, Boca Del Rio, Veracruz, Mexico
}

\begin{abstract}
Oreochromis niloticus (Nile tilapia) is a species having tolerance to low water quality and disease, yet in recent years its cultivation has been faced with problems related to infections with bacteria such as Aeromonas spp., Streptococcus spp., Edwardsiella spp. and Francisella spp., each characterized by mortality between $15 \%$ and $90 \%$ of aquaculture production. These economic losses are associated with poor management practices, minimal producer knowledge of disease control, and the maintenance of overly high densities; which they are directly related to electricity consumption, land use and water management, inputs of raw materials, and manpower for operating links in the value-chain. Mortalities are measured according to the degree of pathogenicity, which depends on the alteration and progression of physiological conditions of the host under the influence of environmental factors, health status and pathogen virulence. There is currently a need to confront and diminish the degree of pathogenicity, and researchers are seeking alternatives that allow the use and application of probiotic bacteria, plant extracts and vaccines. Here, we review the main pathogenic bacteria found in Oreochromis niloticus culture operations and options for controlling the appearance of bacterial pathogens in aquaculture production.
\end{abstract}

Keywords: Tilapia; Bacterial diseases; Degree of pathogenicity

\section{Introduction}

Tilapia are a group of fish having economic, commercial and nutritional importance. Among the commercial species are O. niloticus, O. mossambicus, $O$. aureus, $O$. urolepis hornorum, Tilapia rendalli and T. zilli [1]. According to FAO [1], 99\% of the species are cultivated outside their original habitat, and tilapia are the second most important group of species cultivated worldwide, mainly in the Philippines, Indonesia, Thailand, Malaysia, China, Chile, Mexico, Ecuador, Brazil and Colombia, with production exceeding that for salmonid and carp cultivation [1]. The success of tilapia production is due to their rapid growth, that they are easy to propagate, are tolerant to many environmental conditions, easily accept natural foods and supplements, and have greater resistance to disease and poor water quality. Yet, $90 \%$ of diseases in culture systems are associated with poor management and poor implementation of biosecurity programs. In addition, the lack of producer knowledge regarding the absence or presence of pathogenic risks, the low cost of food production and intensive culture further complicate the issues. Among the disease organisms that cause mortality in tilapia are bacteria such as Flavobacterium columnare, Edwardsiella tarda, Aeromonas spp., Vibrio spp., Francisella spp., Streptococcus agalactiae and S. iniae. Some of these pathogens are distributed throughout tropical and temperate regions where warmwater species, such as Nile tilapia, are commonly cultured. Merck Sharp and Dohme Corp. (MSD Animal Health) [2] mentions that mortalities increase with density (number of fish $\mathrm{m}^{-3}$ ) [3], and James et al. [4] and Bondad-Reantaso et al. [5] indicate that aquacultural health problems and the introduction of species promote the emergence of diseases. According to Snieszko [6], disease is related to the interaction between fish, pathogens and their waterways. When an organism is exposed to a bacterial pathogen in an unfavorable environment (e.g. poor water quality or excess of organic matter), disease incidence is higher because the balance between the pathogen, host and aquatic environment destabilizes. However, fish contain a high bacterial diversity, which results from a symbiotic effect among bacteria and tolerance by fish that protect them when adapting to nutritional changes and assimilation of food in the digestive tract [7].

\section{Bacteria in Fish-Farming: Pathology and Diagnosis}

\section{Streptococcus agalactiae}

The genus Streptococcus is an emerging Gram-positive pathogen in freshwater and marine cultured fish [8]. It is characterized by septicemia and meningoencephalitis. The first case of infection occurred in Japan during the nineteenth century [9]. Infection is primarily with S. agalactiae at a prevalence of 40 to $70 \%$ during rearing of both juveniles and adults. It has been reported in various species of fish around the world, and its geographical distribution includes regions with temperate and tropical climates, including Brazil, China, Malaysia and the United States [10,11]. S. agalactiae has been reported in rainbow trout (Oncorhynchus mykiss), channel catfish (Ictalurus punctatus) and silver sea bream (Rhabdosargus sarba (formerly Sparus sarba)) [11], and it has been detected in terrestrial animals including dogs, pigs, cows, horses and humans [12]. The primary symptoms of infection are erratic swimming, swimming in circles, uncoordinated movements, skin injuries, anorexia or reduced appetite, exophthalmos, corneal opacity, extension of the visceral cavity, abdominal bleeding and swelling, softening of the brain and liver, hepatomegaly and liver paleness, splenomegaly and visceral adhesion $[10,13,14]$. The bacterium also causes 90 to $100 \%$ mortality in O. niloticus with a virulence for $S$. agalactiae based on strain SA20-06 at $6.14 \times 10^{1.17} \mathrm{CFU}(\mathrm{CFU}=$ colony forming units) isolated from different cultures, providing a lethal dose $\left(\mathrm{LD}_{50}\right)$ at $1.12 \times 10^{6} \mathrm{CFU} \mathrm{mL} \mathrm{m}^{-1} 72$ hours after infection $[15,16]$.

*Corresponding author: Landeros-Sánchez, Post Graduate College, Campus Veracruz, via Paso De Ovejas, Tepetates, Municipality of Manlius, Veracruz, Mexico, Tel: 01 (229) 93494 85; Extn. 3007; E-mail: clandero@colpos.mx

Received March 30, 2016; Accepted May 23, 2016; Published May 25, 2016

Citation: Huicab-Pech ZG, Landeros-Sánchez C, Castañeda-Chávez MR, LangoReynoso F, López-Collado CJ, et al. (2016) Current State of Bacteria Pathogenicity and their Relationship with Host and Environment in Tilapia Oreochromis niloticus. J Aquac Res Development 7: 428. doi:10.4172/2155-9546.1000428

Copyright: () 2016 Huicab-Pech ZG, et al. This is an open-access article distributed under the terms of the Creative Commons Attribution License, which permits unrestricted use, distribution, and reproduction in any medium, provided the original author and source are credited. 
Citation: Huicab-Pech ZG, Landeros-Sánchez C, Castañeda-Chávez MR, Lango-Reynoso F, López-Collado CJ, et al. (2016) Current State of Bacteria Pathogenicity and their Relationship with Host and Environment in Tilapia Oreochromis niloticus. J Aquac Res Development 7: 428. doi:10.4172/2155-9546.1000428

Streptococcus is transmitted by direct and indirect contact, with water as the primary route of transmission, mainly through dispersion of infected dead, dying or apparently healthy fish which release the bacteria into the water resulting in the infection of other individuals and cell replication in skin and internal organs (71.2\%) [17]. These bacteria can survive for long periods in water, mud and ponds, and even the equipment used in normal operations, yet sometimes incidence and prevalence are related to elevated temperatures $\left(>27^{\circ} \mathrm{C}\right)[15]$.

In experiments, a concentration of $1 \times 10^{1} \mathrm{CFU}$ and $1 \times 10^{5} \mathrm{CFU}$ caused 80 to $100 \%$ mortality in cultured O. niloticus $[13,17]$. Merck Sharp and Dohme Corp. (MSD Animal Health) [2] confirms the presence of two forms of $S$. agalactiae, Biotype-I and Biotype-II. Biotype-I is characterized by mortalities in juveniles, while BiotypeII by losses of adults with a prevalence of $56 \%$ in China, Indonesia, Vietnam, the Philippines and Latin America [18].

According to Ye et al. [11], this bacterium also reduces feeding efficiency and weight gain, thereby affecting the productive performance of infected organisms. However, some studies have reported the presence of mesophilic bacteria in natural systems. AlHarbi and Uddin [19], for example, determined the presence of 19 species of bacteria, including Streptococcus spp., in samples of water $\left(1.4 \pm 1.5 \times 10^{3}\right.$ to $\left.8.6 \pm 2.7 \times 10^{3} \mathrm{CFU} \mathrm{mL}^{-1}\right)$, gill tissue $(8.7 \pm 1.9 \times$ $10^{5}$ to $\left.2.1 \pm 0.9 \times 10^{6} \mathrm{CFU} \mathrm{g}^{-1}\right)$ and intestinal tracts of tilapia $(2.8 \pm 2.4$ $\times 10^{7}$ to $1.0 \pm 1.6 \times 10^{8} \mathrm{CFU} \mathrm{g}^{-1}$ ), indicating a prevalence $>10 \%$, and with a greater diversification in intestines than in gills. This variation depends on the metabolic activity of fish in relation to the range of water temperatures $[19,20]$.

Pretto-Giordano et al. [10] evaluated the degree of S. agalactiae pathogenesis at different concentrations: $1.5 \times 10^{8} \mathrm{CFU} \mathrm{fish}^{-1}, 5.0 \times 10^{7}$ CFU fish ${ }^{-1}, 2.0 \times 10^{7} \mathrm{CFU} \mathrm{fish}^{-1}$ and $6.0 \times 10^{6} \mathrm{CFU} \mathrm{fish}^{-1}$. They determined that at $1.5 \times 10^{8} \mathrm{CFU}$ fish ${ }^{-1}$ mortality was 67.5 to $90 \%$ during the first 48 hours after intraperitoneal inoculation of tilapia, yielding a cumulative mortality of $44.4 \%$. According to Newman [21], inoculation with S. agalactiae can be by immersion, and intraperitoneal or muscular injection [22,23]. However, the degree of pathogenicity depends on the inoculum concentration as well as the bacterial strain, observation period, host age and weight; temperature, phenotypic diversity and genotype, which also affect strain virulence $[10,15]$.

\section{Francisella spp.}

Francisella is a genus of Gram-negative coccobacillus bacteria that is intracellularly and aerobically facultative [24]. It is classified as an emerging disease of farmed fish and wild species, and the presence or appearance of the pathogen or bacteria in new hosts increases according to the relationship between incidence and prevalence time $[25,26]$.

Francisella has a prevalence of 85 to $90 \%$ in fish aquaculture. It is globally distributed and is reported in Chile, Brazil, Egypt, Costa Rica, Indonesia, Japan and in different European countries [24,27]. The genus Francisella is divided into two subspecies, and both are highly pathogenic according to the environment where they are found. For example, $F$. noatunensis orientalis occurs in tropical zones and $F$. noatunensis noatunensis occurs in temperate zones; its pathogenic harm is caused by direct contact, that is, with water, food and with some vectors of the natural system [25]. The pathogen causes chronic injury due to intracellular infiltration, with abnormalities reported in various species, but mainly $O$. niloticus [28]. It has also been diagnosed in humans, birds, reptiles, crustaceans, and soil and water samples [29,30]. Francisella spp. has been isolated from giant abalone (Haliotis gigantea Gmelin) [31], Atlantic cod (Gadus morhua L.) [27], Nile tilapia (O. niloticus) [22], Atlantic salmon (Salmo salar L.), white bass (Morone chrysops and striped bass (M. saxatilis) [32]. The pathogen is characterized by non-specific external signs such as erratic swimming, exophthalmos, anorexia, anemia and bleeding around the pectoral fins [28], and internal clinical signs such as epithelial hyperplasia in gills, splenomegaly, renomegaly, granulomas, nodes and necrosis in internal organs such as the spleen, heart, liver, kidney, brain and muscles $[33,34]$. The pathogen is transmitted horizontally in water, infecting fish by direct contact [33]. Pathogenicity occurs at temperatures $<25^{\circ} \mathrm{C}$, yet at temperatures between $26.5^{\circ} \mathrm{C}$ and $29.2^{\circ} \mathrm{C}$ there is no mortality of O. niloticus.

\section{Aeromonas hydrophila}

Aeromonas spp. is a genus of Gram-negative facultative pathogens in the Aeromonadaceae family. Within the lineage, four species are listed as the primary agents of septicemia, with the latter the causative agent of hemorrhagic septicemia syndrome or dermal red plague: A. salmonicida (considered the cause of furunculosis), A. sobria, A. canviae and A. hydrophila [35], which are opportunistic pathogens and pollution agents in culture environments. Within Aeromonas, A. hydrophila, A. salmonicida, A. sobria and A. piscicola have been isolated from species of tilapia (Oreochromis spp.), [36] rainbow trout (Oncorhynchus mykiss), Atlantic salmon (Salmo salar), channel catfish (Ictalurus punctatus) and goldfish (Carassius auratus) [35,37]. A. hydrophila has a prevalence between 10 and $85 \%$ at all stages of cultivation, and is considered the most important bacterial agent in cultured freshwater fish [37-40], and has also been reported in other animals, including mammals and humans. Human beings can also suffer from infections with A. sobria, A. hydrophila and A. caviae. It is also latent in hosts with homeothermic and poikilothermic physical activity $[35,41]$. The pathogen causes haemorrhages in skin and gills, and necrosis in internal organs, as well as weakness and anorexia [42]. The genus Aeromonas naturally occurs in many areas, but the degree of pathogenicity depends on species resistance and environmental conditions [40,43]. Aeromonas spp. is a secondary pathogen; its invasiveness depends on previous infection or damage by a primary pathogen or stress such as low dissolved oxygen $\left(\mathrm{mg} \mathrm{L}^{-1}\right)$, high organic content and ammonium, industrial pollution, temperature fluctuations or injury [44,45]. A. hydrophila is a commensal or saprophytic bacterium which predominates in the digestive system and skin $[35,45,46]$. In the cultivation of $O$. niloticus, fish were experimentally injected intraperitoneally with a lethal concentration $\left(1 \times 10^{8} \mathrm{CFU}\right)$ of $A$. hydrophila [47], compared to $1 \times 10^{2}$ and $1 \times 10^{7} \mathrm{CFU}$ fish $^{-1}$. These concentrations increased virulence due to the greater contact of intraperitoneal bacteria with viscera, such as kidney, heart and liver.

$\mathrm{Li}$ and Cai [48] intraperitoneally injected juvenile O. niloticus with A. sobria at $\mathrm{LD}_{50}$ 's of $4.17 \times 10^{3} \mathrm{CFU}, 0.1 \times 10^{2}$ and $0.1 \times 10^{7} \mathrm{CFU} \mathrm{fish}^{-1}$; this pathogen is the causative agent of tail rot in O. niloticus in China. The study revealed that all lethal concentrations revealed dead or dying fish, with the most common symptom being tail rot. During the study various antibiotics also were evaluated to measure their effect against pathogenic strain PY36, to determine if there was more pathogenic sensitivity to the antibiotics oxytetracycline, streptomycin, tetracycline, neomycin and trimethoprim. Pathogenic strain PY36 had greater resistance to the antibiotics ampicillin, chloramphenicol, enrofloxacin and kanamycin.

Yardimci and Aydin [47] and Conroy [44] reported that Aeromonas spp. causes exophthalmia, fluid accumulation, loss of scales and dermal tissue, necrotic damage in gill plates, as well as 
Citation: Huicab-Pech ZG, Landeros-Sánchez C, Castañeda-Chávez MR, Lango-Reynoso F, López-Collado CJ, et al. (2016) Current State of Bacteria Pathogenicity and their Relationship with Host and Environment in Tilapia Oreochromis niloticus. J Aquac Res Development 7: 428. doi:10.4172/2155-9546.1000428

loss of vision due to eye orbital damage. It also causes septicemia in internal organs, especially in liver and kidney, which causes skin ulcers, hemorrhages and edema in fish muscle, thus affecting the innate immune system which is characterized as the first line of defense in an organism, and includes mucous membranes, skin and humoral mechanisms [49,50]. A. hydrophila can be isolated from the surface of the skin and intestine in fish because they produce large amounts of cytotoxins which cause cell necrosis [51]. Rubio-Limonta et al. [52] evaluated the behavior of the pathogen in west, central and eastern Cuba, and determined a larger presence of Aeromonas spp. in intensive culture of Oreochromis spp. compared with bacterial species of the genera Pseudomonas, Enterobacteriaceae, Flexibacter, Flavobacterium, Vibrio and Streptococcus. A. hydrophila has been challenged by using immunostimulants such as glucan (1\%) and Lactobacillus rhamnosus $\left(1 \times 10^{10} \mathrm{CFU} \mathrm{g}^{-1}\right)$ in experimental tilapia cultures, where both treatments were shown to be capable of reducing intestinal damage by bacteria, although the application of lactic acid bacteria can maintain the balance of intestinal microflora [50]. Harikrishnand and Balasundaram [45] mention that $A$. hydrophila invades fish when there is increased stress, similar to that mentioned by Snieszko [6].

\section{Edwardsiella tarda}

Edwardsiella spp. is a Gram-negative strict pathogen. It is the causative agent of septicemia and is commonly housed in the intestines of fish. The genus consists of four species: E. tarda, E. Ictaluri, E. hoshinae and E. anguillimortifera.

E. tarda is a pathogen reported in cultured O. niloticus, Japanese eel (Anguilla japonica), channel catfish (Ictalurus punctatus), red sea bream (Pagrus major), turbot (Scophthalmus maximus) and four-way hybrids of $O$. mossambicus $\times$ O. niloticus $\times$ O. urolepis hornorum x $O$. aureus [53]. It also has been found in dogs, reptiles and birds [54]. Park et al. [54] mention that E. ictaluri is widespread compared to E. tarda, with the latter characterized as causing zoonosis [42]. This pathogen is present in Taiwan, the United States, Venezuela and Japan $[21,53,55]$. The pathogen is present in environments with high temperatures, poor water quality and excess of organic matter; conditions that allow its adherence to and replication within fish cells. Edwardsiellosis provides a clinical picture of sepsis on the inside and outside of fish, including internal organs such as kidney, liver and spleen, and external such as skin, rectum and fins (bleeding), abdominal swelling and dull eyes. Infected fish also show symptoms of exophthalmos, abnormal swimming and spiral movements. However, according to Clavijo et al. [53], the presence of E. tarda in four-way hybrids of tilapia was apparently in healthy individuals, and was determined using biochemical and bacteriological analyses.

\section{Primary pathogenic bacteria in cultured tilapia, Oreochromis} spp.

Currently, the genera Aeromonas, Streptococcus, Edwardsiella and Francisella are the leading causes of mortality of cultured Oreochromis spp., and their presence in freshwater and marine culture is related to the progression of the disease through environmental factors, host health and pathogen virulence. Table 1 shows the presence of pathogenic bacteria in O. niloticus.

\section{Detection Methods for Bacterial Pathogens}

Bacterial pathogens are identified according to their biochemical characteristics. Tests for such characteristics provide an insight into the ability of bacteria to alter specific substrates and synthesize various products [56]. Bacterial cultures are similar in their morphological and microbiological culture characteristics, yet some bacteria are capable of exhibiting differences, according to metabolic reactions regarding catalase, oxidase, indole, lysine and arginine production, and the fermentation of glucose and lactose. In addition to verification tests such as Vogesproskauer, Methyl-red and Gram-stain [56], bacteriological studies allow us to analyze bacteria from water, sediment and tissue environments. Biochemical tests can be applied in various studies to verify the presence of $E$. tarda in four-way hybrids of $O$. niloticus, even if its presence in the host was an asymptomatic reaction [53]. Al-Harbi and Uddin [19] determined the presence of various pathogens such as Vibrio parahaemolyticus, V. alginolyticus, V. vulnificus, Pseudomonas spp., Streptococcus spp. and Shewanella putrefaciens with prevalences between 10 and 58\% in O. niloticus. Whitman and McNair [56] mention that the pathogenicity of bacteria is measured in terms of their ability to invade a host, and whether they are primary or secondary pathogens. A primary pathogen can cause disease in healthy animals within a minimum stress range, while a secondary pathogen causes disease in the presence of a primary pathogen, although the secondary pathogen still significantly contributes to the disease. The degree of bacterial infection is classified into three types: (1) haemorrhagic septicemia (HS), (2) skin ulcers and sores, and (3) chronic loss of senses without signs of disease. Bacterial isolation is performed using selective culture media which are characterized as having nutrient combinations that bacteria require for growth and development of colonies. Such media are composed of tissue extracts from plants and animals, such as meat and yeast [57]. For example, blood agar (BHI), methylene blue agar (MBA), trypticase soy agar (TSB), Columbia agar (CNA) and rams blood agar are needed for identification and isolation of $S$. agalactiae $[10,11]$. For A. hydrophila, blood agar (BHI) is required, as well as biochemical evidence of glucose, maltose and sucrose production and mannitol fermentation [47]. To identify Francisella spp., cysteine and glucose are required, such as in Thayer-Martin agar, heart agar with selective cysteine, bovine haemoglobin, hares blood, trypticase soy agar (TSB), Mueller-Hinton agar and Columbia agar (CNA) $[25,33,39]$. Bergey's Manual of Determinative Bacteriology is commonly used to identify bacterial colonies [58]. This manual was also used by Evans et al. [59], although bacterial detection is currently performed with PCR (Polymerase Chain Reaction) which provides amplification of the 16SrRNA gene in S. agalactiae [11], A. hydrophila [47] and Francisella spp. [24], a gene unique to bacteria.

\section{Strategies to Reduce the Presence of Pathogens: Phytobiotics}

The aquaculture industry is currently considering the use of herbal medicine, or phytotherapy, as an alternative for the reduction of environmental impact and improving the sanitary quality of products, and also helping to prevent diseases caused by pathogenic bacteria in aquatic organisms [60]. Phytotherapy is classified by the World Health Organization (WHO) as the science that studies products of plant origin for the manufacture of drugs and drug synthesis [60]. Plants are an invaluable source of biologically active molecules due to their production of secondary metabolites having pharmacological properties [61], active constituents that include polyphenols, flavonoids, phytoestrogens, isoprenoids, sulfur compounds, phenols, glycosides, saponins, monoterpenes, carotenoids, vitamins, fibers and minerals [62]. In the pharmaceutical industry, plants are considered chemotherapeutic products because they counter bacterial, fungal and degenerative diseases $[60,61,63]$. Punitha et al. [64] evaluated five plant species against infection from Vibrio harveyi in juvenile greasy grouper (Epinephelus tauvina): Bermudagrass (Cynodon dactylon) Indian long 
Citation: Huicab-Pech ZG, Landeros-Sánchez C, Castañeda-Chávez MR, Lango-Reynoso F, López-Collado CJ, et al. (2016) Current State of Bacteria Pathogenicity and their Relationship with Host and Environment in Tilapia Oreochromis niloticus. J Aquac Res Development 7: 428. doi:10.4172/2155-9546.1000428

Page 4 of 10

\begin{tabular}{|c|c|c|c|c|c|}
\hline Author & Pathogen & $\begin{array}{l}\text { Prevalence and } \\
\text { pathogenicity }\end{array}$ & Species & Average size & Signs of illness \\
\hline Clavijo et al. [54] & E. tarda & Presence-absence & $\begin{array}{l}\text { Tilapia three-way hybrid } \\
\text { (O. niloticus } \mathrm{X} \\
\text { O. mossambicus } \mathrm{X} \\
\text { O. aureus) }\end{array}$ & Pre-fattening from $14-20 \mathrm{~g}$ & Asymptomatic signs. \\
\hline \multirow[t]{5}{*}{ Al-Harbi \& Uddin [46] } & A. hydrophila & \multirow{5}{*}{$77 \%$} & \multirow{5}{*}{$\begin{array}{l}\text { Tilapia hybrid (O. } \\
\text { niloticus } X 0 . \text { aureus) }\end{array}$} & \multirow[t]{5}{*}{ Pre-fattening from $30-40 \mathrm{~g}$} & \multirow[t]{5}{*}{ Damage to the digestive tract. } \\
\hline & Shewanella putrefaciens & & & & \\
\hline & $\begin{array}{l}\text { Corynebacterium } \\
\text { urealyticum }\end{array}$ & & & & \\
\hline & Escherichia coli & & & & \\
\hline & V. cholera & & & & \\
\hline \multirow[t]{6}{*}{ Al-Harbi \& Uddin [19] } & V. parahaemolyticus & \multirow[t]{5}{*}{$>10 \%$} & \multirow[t]{6}{*}{ O. niloticus } & \multirow[t]{6}{*}{ Juveniles $134 \pm 151 \mathrm{~g}$} & \multirow{6}{*}{$\begin{array}{l}\text { Lethargy, loss of appetite, exophthalmos, } \\
\text { erratic swimming. }\end{array}$} \\
\hline & V. alginolyticus & & & & \\
\hline & Chryseomonas spp. & & & & \\
\hline & V. vulnificus & & & & \\
\hline & Streptococcus spp. & & & & \\
\hline & Shewanella putrefaciens & $58 \%$ & & & \\
\hline \multirow[t]{7}{*}{ Mauel et al. [33] } & Francisella spp. & \multirow[t]{7}{*}{$5-80 \%$} & \multirow[t]{7}{*}{ O. niloticus } & Rearing $(1-10 \mathrm{~g})$ & \multirow{7}{*}{$\begin{array}{l}\text { Lethargy, loss of appetite, exophthalmos, } \\
\text { erratic swimming. Injuries: splenomegaly } \\
\text { and renomegaly, nodules in liver, kidney, } \\
\text { brain and heart. }\end{array}$} \\
\hline & A. sobria & & & Juveniles (500-750 g) & \\
\hline & A. hydrophila & & & \multirow[t]{5}{*}{ Fattening $(>1000 \mathrm{~g})$} & \\
\hline & E. tarda & & & & \\
\hline & Serratia spp. & & & & \\
\hline & Pseudomonas spp. & & & & \\
\hline & $\begin{array}{l}\text { Plesiomonas } \\
\text { shigelloides }\end{array}$ & & & & \\
\hline \multirow[t]{2}{*}{ Mian et al. [15] } & \multirow[t]{2}{*}{ S. agalactiae } & \multirow[t]{2}{*}{$33-40$ and $100 \%$} & \multirow[t]{2}{*}{ O. niloticus } & Juveniles & \multirow{2}{*}{$\begin{array}{l}\text { Erratic swimming and infection in the } \\
\text { brain. }\end{array}$} \\
\hline & & & & $\begin{array}{l}41.86 \pm 11.57 \mathrm{~g} \\
84.67 \pm 21.1 \mathrm{~g}\end{array}$ & \\
\hline Hernández et al. [17] & S. agalactiae & & Oreochromis spp. & Juveniles of $150 \mathrm{~g}$ & $\begin{array}{l}\text { Erratic swimming and infection in the } \\
\text { brain. }\end{array}$ \\
\hline \multirow{2}{*}{$\begin{array}{l}\text { Rattamachaikunsopon } \\
\text { and Phumkhachorn } \\
\text { (2009) [36] }\end{array}$} & $\begin{array}{l}\text { Flavobacterium } \\
\text { columnare }\end{array}$ & \multirow[t]{2}{*}{$50 \%$} & \multirow[t]{2}{*}{ O. niloticus } & \multirow[t]{2}{*}{$10 \pm 1 \mathrm{~g}$} & \multirow[t]{2}{*}{$\begin{array}{l}\text { Anorexia, lethargy, injury in skin, gills, } \\
\text { scales and operculum. }\end{array}$} \\
\hline & 3.72x $10^{3} \mathrm{CFU}_{\text {fish }}{ }^{-1}$ & & & & \\
\hline Jeffery et al. [24] & Francisella spp. & & O. niloticus & Rearing from $0.5-5 \mathrm{~g}$ & $\begin{array}{l}\text { Exophthalmia, bleeding in the pectoral } \\
\text { fins, pale gills and damage to eyes, } \\
\text { kidneys, liver and spleen. }\end{array}$ \\
\hline Yardimci and Aydin [47] & A. hydrophila & Presence & O. niloticus & Juveniles of $50-80 \mathrm{~g}$ & $\begin{array}{l}\text { Ulcers, bleeding and infiltration of } \\
\text { lymphocytes in liver, heart, kidney and } \\
\text { eyes, and hyperemia, fin and tail rot. }\end{array}$ \\
\hline Li \& Cai [48] & A. sobria & $99.80 \%$ & O. niloticus & $\begin{array}{l}\text { Juveniles of } 20 \pm 0.45 \mathrm{~g} \\
\text { and } 50 \pm 0.83 \mathrm{~g}\end{array}$ & $\begin{array}{l}\text { Abdominal bloating, lack of appetite, } \\
\text { bleeding spots, skin pigmentation, caudal } \\
\text { fin erosion and rotting tail. }\end{array}$ \\
\hline \multirow[t]{2}{*}{ Ye et al. [11] } & \multirow{2}{*}{$\begin{array}{l}\text { S. agalactiae; } \\
\text { Concentration } 1 \times 10^{5} \\
\text { CFU } \mathrm{mL}^{-1}(60-80 \%)\end{array}$} & \multirow[t]{2}{*}{$100 \%$} & \multirow[t]{2}{*}{ O. niloticus } & $\begin{array}{l}\text { Laboratory tests } \\
(10-575 \mathrm{~g})\end{array}$ & \multirow{2}{*}{$\begin{array}{l}\text { Exophthalmos, abnormal swimming, } \\
\text { corneal opacity, abdominal fluid, } \\
\text { hemorrhagic ulcers on the opercula and } \\
\text { pectoral fins. }\end{array}$} \\
\hline & & & & Infection tests $(20-26 \mathrm{~g})$ & \\
\hline Abdullah et al. [56] & S. agalactiae & $70 \%$ & Oreochromis spp. & $100-150 \mathrm{~g}$ & $\begin{array}{l}\text { Erratic swimming, abdominal inflammation } \\
\text { and corneal opacity. Swelling of the brain, } \\
\text { eyes and kidneys. }\end{array}$ \\
\hline $\begin{array}{l}\text { Soto-Rodríguez } \\
\text { et al. [39] }\end{array}$ & $\begin{array}{l}\text { Aeromonas dhakensis, } \\
\text { Pseudomonas mosselii } \\
\text { and Microbacterium } \\
\text { paraoxydans }\end{array}$ & $40-100 \%$ & O. niloticus & $5-10 \mathrm{~g}$ & $\begin{array}{l}\text { Lethargy, erratic swimming, skin } \\
\text { discoloration, loss of scales, lateral } \\
\text { blindness, red or opaque eyes and/or } \\
\text { exophthalmos. }\end{array}$ \\
\hline
\end{tabular}

Table 1: Presence of pathogenic bacteria in cultured Oreochromis niloticus.

pepper (Piper longum L.), gale of the wind (Phyllanthus niruri L.), coat buttons (Tridax procumbens L.) and garden ginger (Zingiber officinale Roscoe). The plants improved non-specific defense mechanisms and intra- and extra-cellular respiration. Abasali and Sudagar [65] determined that incorporating extracts of sweet basil (Ocimum basilicum L.), cinnamon (Cinnamomum verum J. Presl) (formerly $C$. zeylanicum), English walnut (Junglans regia L.) and water mint (Mentha aquatica L.) (formerly $M$. piperita) at concentrations of $0.0,250,500$, 1000 and $1250 \mathrm{mg} \mathrm{kg}^{-1}$ against $A$. hydrophila $\left(1 \times 10^{8} \mathrm{CFU}\right.$ fish $\left.{ }^{-1}\right)$ enhanced non-specific immunity and increases resistance to infection and survival of common carp Cyprinus carpio L. by $91.4 \%$. Sankar et al. [66] mention that the application of Eastern purple coneflower (Echinacea purpurea) extracts increases growth and reproductive behavior during early larval stages of angelfish (Pterophyllum scalare). Park and Choi [67] show that the use of common selfheal (Prunella vulgaris L.) (Lamiaceae) extract induces specific and non-specific immune responses in fish, so it could be used as a dietary supplement. Also, probiotics can be used, which are commonly made up of lactic 
acid bacteria, Vibrio spp. strains, Bacillus spp., Lactobacillus and unicellular fungi, such as the yeast Saccharomyces cerevisiae $[57,68,69]$. In some studies, including those of Merrifield et al. [70], the application of probiotics increases health, disease resistance and growth, reduces defects, improves intestinal morphology and maintains microbial balance. Among the reports on the use of probiotics, Aly et al. [71] isolated 15 probiotic strains, including Bacillus pumilus, B. firmus and Citrobacter freundii (Braak), demonstrating that there was no presence of disease from $A$. hydrophila after fish were fed a diet of $B$. pumilus and a mixture of $C$. freundii and $B$. pumilus. Abdel-Tawwab et al. [68] evaluated the yeast Saccharomyces cerevisiae in O. niloticus against $A$. hydrophila and indicated that the addition of yeast increased available protein in organisms, aside from functioning as an alternative for disease prevention. Pirarat et al. [72] mention that the application of lactic acid bacteria, Lactobacillus rhamnosus GG, in juvenile $O$. niloticus with an average weight of 30-50 g, allowed villous growth in all parts of the intestine, mainly in the proximal part and midgut. Further, the population of intra-epithelial lymphocytes was significantly higher compared to the control group, indicating that this bacterium functions as a regulator of the intestinal immune system.

\section{Host perspectives}

Aquatic host immune system: Infectious disease depends on the interaction and cyclical balance among pathogens, hosts and environment (biological and ecological variables acting as an integrated system in the aquatic habitat) $[6,73,74]$. According to Hedrick [74], host variables include the immune system, genetic influence and nutrition; variables determining the degree of resistance and susceptibility to disease. They are connected with immune system function, primarily to control diseases that impact optimal biological, chemical and physical functions which comprise host immune defense. Among the means of defense are functions against pathogenic microorganisms and immunosurveillance for autoimmune and allergen diseases [75]. In simpler terms, disease is a deviation from normal physiological functions, and can be benign or insidious depending on the cause. For example, the causes of mortality in aquaculture are the result of infections with biological agents, but they also act jointly with compounds or chemicals, metals, pesticides, and nutritional and environmental factors [76,77].

Hosts have two forms of immune response, humoral and cellular, which are triggered by exogenous and endogenous aggression [75]. The immune system is integrated, where the innate immune system activates the adaptive immune system in response to infection and uses mechanisms of the innate immune system to eliminate non-beneficial microorganisms [75,78]. The innate immune system is considered the first line of host defense which is present in all multicellular organisms. This first line responds the same way to different stimuli and distinguishes common infection, but not finer details of microorganism groups [75,79]. Its main components are comprised of physical and chemical barriers, phagocytic cells, natural killer cells, complement system, cytokines and Toll receptors [75]. The innate immune system remembers exposure to specific antigens, if the level of contamination is the same as the first time the innate immune system was exposed, there is no reaction. Among the physical barriers in fish are the skin mucus and the skin itself, which contain a large number of antigenic and internal substances, such as monocytes, macrophages and non-specific cytotoxic cells [23]. Host health depends on humoral and cellular immune responses which vary among individuals in a population. One of the causes most studied in fish is stress on the immune system. Over the last two decades, the relationship among the immune, nervous and endocrine systems has been shown to act as a tridirectional system $[23,80]$.

In aquaculture, stress in fish is determined by the period of adaptation to changes in their aquatic environment, where symptoms are associated with lack of oxygen, high densities, handling, and changes in temperature and pollutants in the water; where there is no balance among the host, pathogen and the aquatic environment. In fish, stress arises from bacterial and parasitic diseases as the first route of infection in aquaculture. Nutritional status is also a factor that affects the immune system. Nutrition is the process by which the body absorbs and assimilates the nutrients necessary for function and energy $[81,82]$. For example, nutrition maintains the homeostatic balance of the body at macrosystemic and molecular levels, ensuring that all physiological events are carried out properly to provide adequate health and reduce disease. The lack of some vitamins such as $\mathrm{C}$ and $\mathrm{E}$ alters macrophage functions such as leucocyte phagocytosis, reduces intestinal flora and resistance to bacteria, all of which are influenced by the hormone cortisol which affects protein, carbohydrate and lipid metabolism [83]. Aquaculture systems promote a better balance among hosts, the culture medium and pathogens, making it essential to better understand the role of each factor in production systems and those beginning to emerge that have negative influences. Host characteristics are a function of the genetic characteristics of a species, its age, size and development, its nutritional and reproductive needs, and its immune defense mechanisms (the potential for susceptibility and adaptation to pathogens) [74].

\section{Pathogen perspectives}

The pathogenicity and infection are associated with stress and environmental variables such as temperature, salinity, oxygen, ammonium, nitrates and nitrites. Pathogens are considered obligatory when they are directly related to host infection, and are contained within structures such as cell walls, plasma membranes, cytoplasm, ribosomes and nuclear regions. Facultative pathogens survive in the absence of a host and are associated with structures such as capsules, flagella, hair, endospores and cytoplasmic inclusions. Hedrick [74] indicates that to be a disease pathogen depends on the strain, biotype, serotype and genotype, as well as the dose and number of pathogens, duration and route of entry into the host. Their conditions for growth and development depend on the $\mathrm{pH}$, temperature, osmotic pressure, presence of oxygen (aerobic and anaerobic), presence of $\mathrm{CO}_{2}$, humidity, dryness and light. The pathogen-host systems generally maintain a balanced relationship between host, pathogen and environment, with the immune system being the primary regulator of the interaction among these indicators [73,78]. That is, disrupting the balanced interaction among pathogens, environment and hosts, for natural (e.g. weather) or anthropogenic reasons (e.g. aquacultural intensification and management), can promote active infectious diseases, leading to physiological, nervous and digestive system abnormalities [81]. Thus, to avoid increasing the presence of infectious agents, aquaculture must use antibiotics, which can increase bacterial resistance with excessive use if dose guidelines recommended by the FDA (Food and Drug Administration) are not respected.

The development of drug-resistant strains provides a better understanding of the physiological and molecular mechanisms responsible for the genetic basis of resistance in bacteria and hosts. According to Burridge et al. [84] and Bravo et al. [85] antibiotic resistance is associated with the natural or acquired ability of a pathogen to survive in the presence of an antibiotic or chemical 
where at first it was susceptible [3]. The use of antibiotics is promoted by aquaculture extension to increase fish densities, yet this action promotes more problems with disease, so there is a need to use chemicals to combat and control, prevent or correct, the presence of infectious diseases $[3,84,85]$. Thus, the indiscriminate use of antibiotics generates more severe disorders such as toxicity, adverse environmental effects, genetically based resistance in bacteria, parasites and viruses, and antibiotic residues in tissues of aquatic organisms, thus impacting fish and human health (established by the World Health Organization (WHO) and the Codex Alimentarius; [86]). There are several options for counteracting disease, or preventing, treating or controlling the incidence of infection, such as using antibiotics, probiotics, antimicrobials, vaccines, genetic improvement of aquatic organisms, immunostimulants and good management practices [87-89]. To control the excessive use of drugs and chemicals, viable alternatives for inhibiting pathogens must be explored, such as the use of vaccines [22], which are composed of inactive bacteria or whole cell suspensions inactivated with formalin. Vaccines are antigens that stimulate the immune system to produce antibodies that help prevent specific bacterial diseases [89]. The first vaccines that were marketed in the 1970s were from the genus Vibrio spp [21]. Vaccines are tools that minimize treatment costs when diseases occur. Vaseeharan and Thaya [89] indicated that vaccines can be made from inactive bacteria, DNA and viruses. Antibiotics are considered chemical and biological substances produced by living organisms that have the ability to inhibit growth and destroy bacteria using a minimal concentration. They act according to their biological potential, toxicity and mode of action to interfere with biochemical reactions in pathogens by blocking metabolic pathways or the synthesis of macromolecules essential for the bacterium. The metabolic pathways are used to obtain chemical energy from storage (biosynthesis), conversion of exogenous nutrient precursors by bacteria, and degradation of molecules used for mobility and nutrient uptake [90]. This happens because bacteria can modify certain aspects of themselves, such as R plasmids, which are related to drug resistance or heavy metal tolerance, providing increased capacity for colonization and virulence [91]. Plasmids are extra-chromosomal DNA molecules, double-stranded, circular, and capable of replication of the bacterial chromosome.

Meanwhile, antibiotics are natural or synthetic, where natural antibiotics are produced by living organisms such as bacteria and fungi, and synthetic antibiotics are produced by chemical synthesis, such as the nitrofurans. Their potential depends on the capacity to act on a type of bacteria, various inactivated bacteria, or on Gram-positive and negative bacteria, and can be considered as small, medium and large, regarding their spectrum of action. Antibiotics exhibit bacteriostatic and bactericidal activity, the first of which stops and prevents the growth of a bacterial population, and the second has a lethal and rapid action against bacteria, an effect that is irreversible [89]. The mechanisms of action are focused on key components such as cell walls, cell membranes, and the synthesis of proteins and nucleic acids. The effectiveness of antibiotics depends on the condition of the pathogen; some bacterial pathogens produce proteinaceous toxins which allow them to live apart from the defense systems of the host. Host cell cycles are involved in immune response processes, maintenance of epithelial barriers and cell differentiation, processes that directly affect growth and colonization by pathogenic bacteria in an aquatic host. However, such processes and components can be manipulated by bacterial pathogens to directly affect the functions of the cell components [89]. Currently, the demand for aquacultural products requires avoiding the use of antibiotics and chemotherapy, and embracing alternatives such as those derived from medicinal plants (e.g. immunostimulants) which have the advantage of strengthening the immune system to control diseases in aquacultural systems [92]. Immunostimulants are natural compounds that increase host resistance to pathogenic diseases, but their disadvantage is that they must be orally administered over the long term, leading to a decrease in efficiency and immunosuppression from overuse $[93,94]$.

Bacterial communication in fish is similar to that in higher organisms; they have communication behaviors, cooperation and complex association, such as organizations, plasmid transfer, virulence, symbiosis and adaptation to a place. The latter is associated with favorable conditions such as when the bacterial assembly experiences a danger such as a defense mechanism. All of these processes are regulated by another process known as quorum balance [91,95]. Within the bacterial community there are social interactions that allow for synchronization to maintain a common behavior, to act as multicellular organisms, but only when the bacterial assemblage meets other commitments for individuality and group diversity [91]. The groups of pathogenic and non-pathogenic bacteria have the ability to communicate among their cells, a process called quorum sensing. In this process, the bacteria can sense how many cells there are based on the production and accumulation of signaling molecules and pheromones, which are exported throughout their environment to communicate with other bacteria through their molecular receptors $[91,96]$. The benefit provided by this type of bacterial communication is that bacteria can coordinate and respond to sudden changes in environmental factors, such as the availability of nutrients and the presence of microbes or toxins in their environment, acting as a group to obtain better results than they would have individually [91]. Thus, bacteria in an environment (natural or otherwise) can form species groups which act cooperatively toward a common goal, such as defense and attack by using high levels of auto-induced molecules/pheromones which promote adaptation and interaction of bacteria in environments where bacterial dispersión is difficult, such as within a host.

\section{Environmental perspectives}

The environmental effects on hosts and pathogens are paramount in the onset of disease [73]. The environmental factors include physical and chemical characteristics which are measured and analyzed over time and space. The variables directly related to imbalance among the environment, pathogens and hosts are temperature, $\mathrm{pH}$, organic matter, dissolved oxygen, nitrites and nitrates. For example, low temperature effects on the immune system are reflected in the cellular components, primarily impairing the function of T-helper cells $[73,97]$. Anthropogenic activity can also directly affect the diversity and density of biota, increasing the presence of bacterial, parasitic and viral infectious diseases [79]. For example, the construction of hydroelectric dams, excessive logging of large areas of land, agriculture (including irrigation and grazing), and mining have resulted in excessive overland runoff leading to eutrophication, and the accumulation of pollutants, pesticides and heavy metals which cause biological changes in natural ecosystems that break the natural balance among hosts, pathogens and the environment $[4,77,98,99]$. This results in economic and environmental impacts due to the influence of stress from high densities and exposure to toxic chemicals and pollutants which promote outbreaks of fish diseases and noxious stimuli $[73,82,100]$. One of the most studied intrinsic factors is stress on fish immune systems, which need a period of adaptation to environmental changes. In fish, stress is affected by levels of cortisol in combination with behavioral responses [101]. Cortisol redistributes immune system cells, as well as elements 
Citation: Huicab-Pech ZG, Landeros-Sánchez C, Castañeda-Chávez MR, Lango-Reynoso F, López-Collado CJ, et al. (2016) Current State of Bacteria Pathogenicity and their Relationship with Host and Environment in Tilapia Oreochromis niloticus. J Aquac Res Development 7: 428. doi:10.4172/2155-9546.1000428

Page 7 of 10

of the innate immune system, thus providing the first line of defense in a host $[101,102]$.

Stress is an adaptation response to a perceived threat, an action to preserve the individual. According to Iwama [103], stress is defined as the response of a cell or organism to significant deviations from a normal resting state. This imbalance results in collateral damage regarding energy demands from the physiological system, reduces growth, and suppresses the reproductive and immune systems. Stress in fish can be primary, secondary or tertiary, and results from the release of catecholamines, activation of the hypothalamus-pituitaryinterenal axis (HPI), and cortisol levels in the blood [81,101,102]. According to Iwama [103], stress is the primary factor in fish health, but it does not relate directly to poor environmental conditions. Thus, aquacultural practices should be carried out correctly to avoid stress and physical injury during handling, which could lead to increased disease susceptibility from internal sources, as well as infectious pathogens entering the skin. Stress can be acute or lethal, chronic or sublethal, or chronic direct or indirect, the variations of which depend on exposure to chemicals, changes in environmental factors, exposure to short and long-term stressors, and eventually damage to metabolic functions and behaviors [104].

It is necessary to plan and follow management protocols for optimum system design in order to obtain a healthy and sustainable aquacultural operation that involves fish and consumer health [81]. Natural freshwater and marine systems are currently experiencing increased pollution and contamination from anthropogenic activity, indicating environmental stress [104]. In aquaculture, stress can be related to the dominance hierarchy in a population, transportation and vaccination practices $[104,105]$. It can also be related to high densities, sudden changes in temperature, trauma, chemical stress from endogenous and exogenous contaminants, and from nutritional deficiencies in the diet $[82,104]$, all of which can affect cellular organization, population structure and organismal physiology. Diseases in aquaculture are due to low immune responses, suggesting that one solution is to manipulate the microbiota that exist in production systems, pathogens which can be controlled by using beneficial microbes, thus maintaining the host and pathogen in balance without adverse effects. Therefore, it is necessary to manipulate bacterial populations, but to do so requires knowing the type of bacteria present, their abundance, function and community composition, which together lead to complex cooperative behaviors [95]. Such aquatic biological and social systems are in balance through the interaction among pathogenic or beneficial bacterial communities, the environment and hosts, such that all members fulfill the basic requirements for functionality and benefits toward a common goal $[6,73]$. The whole system functions similar to a living system because each group has the ability to self-organize relative to the conditions at hand (Figure 1) [106,107].

\section{Conclusion}

Infectious diseases caused by pathogenic bacteria in cultured tilapia cause great economic and ecological losses, so it is necessary to implement optimal management and biosafety programs in production systems in order to achieve sustainable aquaculture in ecological, economic and social terms. Among the action strategies, it is necessary to provide interdisciplinary studies, which allow for the incorporation of veterinary, epidemiological and biological approaches, and to simultaneously incorporate trained staff for diagnoses, acquisition of knowledge, and training of producers. Among the strategies available for the prevention of bacterial diseases are the management of new biosecurity programs, effective vaccination, stimulation of non-specific host defense mechanisms, use of healthy microorganisms such as probiotics, and herbal medicine. Institutional collaboration also helps in the development of programs for disease prevention and control. At present, there is no information on losses in terms of production costs from disease outbreaks in O. niloticus. Known costs include expenses for antibiotics and parasiticides and their application, food quantity, water, energy, as well as private or public investment in aquaculture

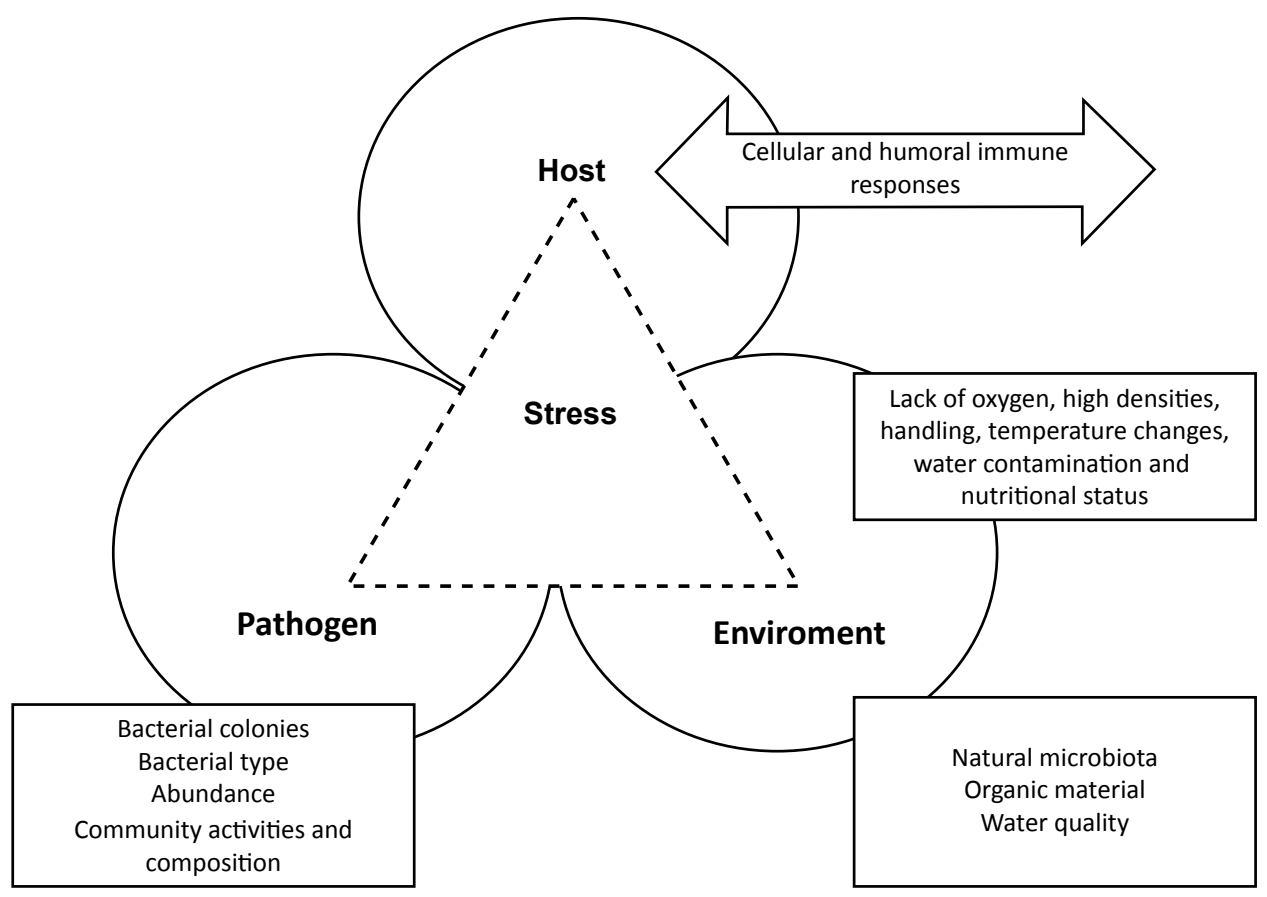

Figure 1: Conceptual diagram of equilibrium among hosts, pathogens and the environment in aquatic systems. 
Citation: Huicab-Pech ZG, Landeros-Sánchez C, Castañeda-Chávez MR, Lango-Reynoso F, López-Collado CJ, et al. (2016) Current State of Bacteria Pathogenicity and their Relationship with Host and Environment in Tilapia Oreochromis niloticus. J Aquac Res Development 7: 428. doi:10.4172/2155-9546.1000428

research. Therefore, it is necessary to offer clean products to consumers, reducing the induction of bacterial resistance and mitigating effects on ecological systems by looking for alternatives such as the use of probiotics, immunostimulants, organic acids and essential oils, which can be used to reduce the use of antibiotics in fish farming.

\section{Acknowledgement}

Thanks to the Consejo Nacional de Ciencia y Tecnología (CONACYT), Colegio de Postgraduados Campus Veracruz and Instituto Tecnológico de Boca del Río (ITBOCA) for their financial support. Thanks are also due to the M.C. Juan Manuel Hernández Pérez for his assistance in the formatting of the manuscript.

\section{References}

1. FAO (Food and Agriculture Organization of the United Nations) (2014) World review of fisheries and aquaculture. The State of World Fisheries and Aquaculture. (SOFIA), Rome, Italy.

2. MSD Animal Health (2011) Bacterial disease in warm water fish: New strategies for sustainable control. Natal, Brazil. Held in conjunction with the World Aquaculture Society Conference.

3. Krkošek M (2010) Host density thresholds and disease control for Fisheries and aquaculture. Aquaculture Environment Interactions 1: 21-32.

4. James SD, Egna HS, Chopin T, Peterson MS, Cao L, et al. (2013) Responsible Aquaculture in 2050: Valuing local conditions and human innovations will be key to success. Bioscience 63: 255-262.

5. Herrscher GE (2003) Pensamiento sistémico; caminar el cambio o caminar el camino. (1stedn) 2 reimp. Buenos Aires, Granica 272.

6. Snieszko SF (1975) History and present status of fish diseases. J Wildl Dis 11: $446-459$.

7. Huong NTT, Thuy HL, Gallardo WG, Thanh HN (2014) Bacterial population in intensive tilapia (Oreochromis niloticus) culture pond sediment in Hai Duong province, Vietnam. Interntional Journal of fisheries and aquaculture 6: 133-139.

8. Kümmerer K (2009) Antibiotics in the aquatic environment-a review-part I. Chemosphere 75: 417-434.

9. Hoshina T, Sano T, Morimoto $Y$ (1958) A Streptococcus pathogenic to fish. Journal in the Tokyo University of Fisheries 44: 57-58.

10. Pretto-Giordano LG, Eckehard-Müller E, De Freitas JC, Gomes da Silva V (2010) Evaluation of the pathogenesis of Streptococcus agalactiae in Nile tilapia (Oreochromis niloticus). Brazilian Archives of Biology and Technology 53: 87-92

11. Ye X, Li J, Lu M, Deng G, Jiang X, et al. (2011) Identification and molecular typing of Streptococcus agalactiae isolated from pond-cultured tilapia in China Fisheries Science 77: 623-632.

12. Johri AK, Paoletti LC, Glaser P, Dua M, Sharma PK, et al. (2006) Group B Streptococcus: global incidence and vaccine development. Nat Rev Microbiol 4: 932-942.

13. Ali FA, Hassan Hj MD, Saleha AA, Siti KB, Milud A (2011) Pathogenicity of Streptococcus agalactiae isolated from a fish in Selangor to Juvenile Red tilapia (Oreochromis sp.). Journal of Animal and Veterinary Advances 10: 914-919.

14. Figueiredo CP, Carneiro O, Faria FC, Costa GM (2006) Streptococcus agalactiae associado à meningoencefalite e infecção sistêmica em tilápiado-nilo (Oreochromis niloticus) no Brasil. Arquivo Brasileiro de Medicina Veterinária e Zootecnia 58: 678-680.

15. Mian GF, Godoy DT, Leal CA, Yuhara TY, Costa GM, et al. (2009) Aspects of the natural history and virulence of $\mathrm{S}$. agalactiae infection in Nile tilapia. Vet Microbiol 136: 180-183.

16. Bondad-Reantaso MG, Subasinghe RP, Arthur JR, Ogawa K, Chinabut S, et al. (2005) Disease and health management in Asian aquaculture. Vet Parasitol 132: $249-272$.

17. Hernández E, Figueroa J, Iregui C (2009) Streptococcosis on a red tilapia, Oreochromis sp., farm: a case study. J Fish Dis 32: 247-252.

18. Salvador R, Zanolo R, Cericato $L$ (2011) The impact of Streptococcus on tilapia in Brazil and efficacy of AquaVac ${ }^{\circledR}$ Strep Sa for managing the disease under controlled conditions. Proceedings: Bacterial Diseases of Warmwater Fish: New Strategies for Sustainable Control. The World Aquaculture Society Conference, Brazil.
19. Al-Harbi A, Uddin N (2005) Bacterial diversity of tilapia (Oreochromis niloticus) cultured in brackish water in Saudi Arabia. Aquaculture 250: 566-572.

20. Al-Harbi AH (2003) Feacal coliforms in pond water, sediments and hybrid tilapia (Oreochromis niloticus $x$ Oreochromis aureus) in Saudi Arabia. Aquaculture Research 34: 517-524.

21. Zamri-Saad M, Amal MNA, Siti-Zahrah A (2010) Pathological changes in red Tilapias (Oreochromis spp.) naturally infected by Streptococcus agalactiae. Journal of Comparative Pathology 143: 227-229.

22. Intervet (2009) Manejo de Streptococcus en Peces de Aguas Cálidas. Memorias Intervet/Shering-Plough Animal Health. Veracruz, México.

23. Vásquez-Piñeros MA, Rondón-Barragán IS, Restrepo-Betancur LF, EslavaMocha PR (2012) Estudio clínico y hematológico de una infección experimental con Aeromonas hydrophila y Edwardsiella tarda en tilapia, Oreochromis sp. Orinoquia, 14: 33-44

24. Jeffery KR, Stone D, Feist SW, Verner-Jeffreys D (2010) An outbreak of disease caused by Francisella spp. in Nile tilapia Oreochromis niloticus at a recirculation fish farm in the UK. Diseases of Aquatic Organisms 91: 161-165.

25. Colquhoun DJ, Duodu S (2011) Francisella infections in farmed and wild aquatic organisms. Vet Res 42: 47

26. Newman SG (1993) Bacterial vaccines for fish. Annual Review of Fish Diseases 3: $145-185$.

27. Ottem KF, Nylund A, Karlsbackk E, Friis-Moller A, Krossoy B, et al. (2007) New species in the genus Francisella (Gammaproteobacteria; Francisella); Francisella piscicida sp. nov. isolated from cod (Gadus morhua). Archives of Microbiology 188: 547-550

28. Soto E, Hawke JP, Fernandez D, Morales JA (2009) Francisella sp., an emerging pathogen of tilapia, Oreochromis niloticus (L.), in Costa Rica. J Fish Dis 32: 713-722.

29. Müller W, Bocklisch H, Schüler G, Hotzel H, Neubauer H, et al. (2007) Detection of Francisella tularensis subsp. holarctica in a European brown hare (Lepus europaeus) in Thuringia, Germany. Veterinary Microbiology 123: 225-229.

30. Woolhouse MEJ, Dye C (2001) Population biology of emerging and reemerging pathogens. Philosophical Transactions of the Royal Society of London, Series B, Biological Sciences 356: 981-982.

31. Kamaishi T, Miwa S, Goto E, Matsuyama T, Oseko N (2010) Mass mortality of giant abalone Haliotis gigantea caused by a Francisella sp. bacterium. Dis Aquat Organ 89: 145-154.

32. Ostland VE, Stannard JA, Creek JJ, Hedrick RP, Ferguson HW, et al. (2006) Aquatic Francisella-like bacterium associated with mortality of intensively cultured hybrid striped bass Morone chrysops $\times$ M. saxatilis. Diseases of Aquatic Organisms 72: 135-145.

33. Mauel MJ, Soto E, Moralis JA, Hawke J (2007) A piscirickettsiosis-like syndrome in cultured Nile tilapia in Latin America with Francisella spp. as the pathogenic agent. J Aquat Anim Health 19: 27-34.

34. Ottem KF, Nylund A, Karlsbakk E, Friis-Møller A, Kamaishi T (2009) Elevation of Francisella philomiragia subsp. noatunensis Mikalsen et al. (2007) to Francisella noatunensis comb. nov. [syn. Francisella piscicida Ottem et al. (2008) syn. nov.] and characterization of Francisella noatunensis subsp. orientalis subsp. nov., two important fish pathogens. Journal of Applied Microbiology 106: 1231-1243.

35. Austin B, Austin DA (2012) Aeromonadaceae representatives (motile aeromonads). Bacterial fish pathogens-diseases of farmed and wild fish (5thedn). Springer, Dordrecht, The Netherlands.

36. Rattanachaikunsopon P, Phumkhachorn P (2009) Potential of Chinese chive oil as a natural antimicrobial for controlling Flavobacterium columnare infection in Nile tilapia Oreochromis niloticus. Fish Science 75:1431-1437.

37. Molnár K, Csaba G (2005) Sanitary management in Hungarian aquaculture. Vet Res Commun 29 Suppl 2: 143-146.

38. Beaz-Hidalgo R, Romaldo JL, Figueras MJ (2012) Expresión génica en peces a causa de infecciobes causadas por Aeromonas spp. Revista Científica de la Sociedad Española de Acuacultura 37: 113-122.

39. Soto-Rodríguez SA, Cabanillas-Ramos J, Alcaraz U, Gómez-Gil B, Romalde $\mathrm{JL}$ (2013) Identification and virulence of Aeromonas dhakensis, Pseudomonas mosselii and Microbacterium paraoxydans isolated from Nile tilapia, 
Citation: Huicab-Pech ZG, Landeros-Sánchez C, Castañeda-Chávez MR, Lango-Reynoso F, López-Collado CJ, et al. (2016) Current State of Bacteria Pathogenicity and their Relationship with Host and Environment in Tilapia Oreochromis niloticus. J Aquac Res Development 7: 428. doi:10.4172/2155-9546.1000428

Oreochromis niloticus, cultivated in Mexico. Journal of Applied Microbiology 115: 654-662.

40. Beaz Hidalgo R, Figueras MJ (2012) Molecular detection and characterization of furunculosis and other aeromonas fish infections, Health and Environment in Aquaculture. 97-132.

41. Fukuda Y, Okamura A, Nishiyama M, Kawakami H, Kamaishi T, et al. (2002) Granulomatosis of cultured three-line grunt Parapristipoma trilineatum caused by an intracellular bacterium. Fish Pathology 37: 119-124

42. Bastardo A, Ravelo C, Castro N, Calheiros J, Romalde JL (2012) Effectiveness of bivalent vaccines against Aeromonas hydrophila and Lactococcus garvieae infections in rainbow trout Oncorhynchus mykiss (Walbaum). Fish \& Shellfish Immunology 32:756-761.

43. Woo PTK, Bruno DW (2010) Edwardsiella septicaemias. Fish diseases and disorders. Viral, bacterial and fungal infections. (2ndedn). Wallingford, CABI International.

44. Conroy G (2014) Enfermedades de tilapia más frecuentes en América Latina y el Caribe. $9^{\circ}$ Foro Internacional de Acuacultura, celebrado en Guadalajara, México. World Aquaculture Society.

45. Harikrishnand R, Balasundaram C (2005) Modern trends in Aeromonas hydrophila disease management with fish. Reviews in Fisheries Science 13: 281-320.

46. Al-Harbi A, Uddin MN (2004) Seasonal variation in the intestinal bacterial flora of hybrid tilapia (Oreochromis niloticus $x$ Oreochromis aureus) cultured in earthen ponds in Saudi Arabia. Aquaculture 229: 37-44

47. Yardimci B, Aydin Y (2011) Pathological findings of experimental Aeromonas hydrophila infection in Nile tilapia (Oreochromis niloticus). Ankara Üniversites Veteriner Fakültesi Dergisi 58: 47-54.

48. Li Y, Cai SH (2011) Identification and pathogenicity of Aeromonas sobria on tail-rot disease in juvenile tilapia Oreochromis niloticus. Curr Microbiol 62 623-627.

49. Faktorovich KZ (1969) Histological changes in the liver, kidneys, skin and brain of fish sick with red rot. Infectious diseases of fish and their control. Division of Fisheries Research, Bureau of Sport Fisheries and Wildlife, Washington, DC.

50. Suchanit N, Kunihiko F, Masato E, Masashi M, Takayuki K (2010) Immunologica effects of glucan and Lactobacillus rhamnosus GG, a probiotic bacterium, on Nile tilapia Oreochromis niloticus intestine with oral Aeromonas challenges. Fish Science 76: 833-840.

51. Donta ST, Haddow AD (1978) Cytotoxic activity of Aeromonas hydrophila. Infect Immun 21: 989-993.

52. Rubio-Limonta M, Cabrera-Campo A, Silveira-Coffigny $R$, Yaraina-Aguilera $S$ (2010) Variabilidad bacteriana en Oreochromis spp. durante las estaciones de Iluvia y seca, cultivadas en ambientes dulceacuícola en diferentes regiones de Cuba. Revista Electrónica de Veterinaria 11: 1695-7504.

53. Burr SE, Goldschmidt-Clermont E, Kuhnert P, Frey J (2012) Heterogeneity of Aeromonas populations in wild and farmed perch, Perca fluviatilis L. J Fish Dis 35: $607-613$

54. Clavijo AM, Conroy G, Conroy DA, Santander J, Aponte F (2002) First report of Edwarsiella tarda from tilapias in Venezuela. Bulletin of the European Association of Fish Pathology 22: 280-282.

55. Park SB, Aoki T, Jung TS (2012) Pathogenesis of and strategies for preventing Edwardsiella tarda infection in fish. Vet Res 43: 67

56. Abdullah S, Omar N, Sabri Mohd YSM, Obukwho EB, Nwunuji TP, et al. (2013) Clinicopathological features and immunohistochemical detection of antigens in acute experimental Streptococcus agalactiae infection in red tilapia (Oreochromis spp.). SpringerPlus 286: 1-7.

57. Abdel-Tawwab M, Abdel-Rahman A, Ismael NE (2008) Evaluation of commercial live bakers' yeast, Saccharomyces cerevisiae, as a growth and immunity promoter for fry of Nile tilapia, Oreochromis niloticus (L.) challenged in situ with Aeromonas hydrophila. Aquaculture 280: 185-189.

58. Whitman KA, MacNair NG (2004) Finfish and Shellfish. Bacteriology Manual. Techniques and Procedures. lowa State Press. Blackwell Publishing.

59. Holt JG, Krieg NR, Sneath PHA, Williams ST (1994) Bergey's Manual of Determinative Bacteriology, (9thedn). Williams and Wilkins, Baltimore, Maryland, USA.
60. Cristea V, Antache A, Grecu I, Docan A, Dediu L, et al. (2012) The use of phytobiotics in Aquaculture. University of Agricultural Sciences and Veterinary Medicine lasi. Lucrari Stiintifice-Seria Zootehnie, 57: 250-255.

61. Prieto A, Ocampo AA, Fernández A, Pérez MB (2005) El empleo de medicina natural en el control de enfermedades de organismos acuáticos y potenciales de uso en Cuba y México. Revista Especializada en Ciencias Químico Biológicas, Junio. Universidad Nacional Autónoma de México 8: 38-49.

62. Serrano DME, López L, Sainz ET (2006) Componentes bioactivos de alimentos funcionales de origen vegetal. Revista Mexicana de Ciencias Farmacéuticas 37: $58-68$

63. Evans JJ, Klesius PH, Gilbert PM, Shoemaker CA, Al SMA, et al. (2002) Characterization of b-hemolytic group $B$ Streptococcus agalactiae in cultured sea bream, Sparus auratus L., and wild mullet, Liza klunzingeri, in Kuwait. Journal of Fish Diseases 25: 505-513

64. Aguilar CN, Rodríguez-Herrera R, Saucedo-Pompa S, Jasso-Cantú D (2004) Fitoquímicos sobresalientes del semidesierto mexicano de la planta a los químicos naturales y a la biotecnología. Proyecto Conafor-Conacyt2004-C01-13

65. Punitha SM, Babu MM, Sivaram V, Shankar VS, Dhas SA, et al. (2008) Immunostimulating influence of herbal biomedicines on nonspecific immunity in Grouper, Epinephelus tauvina, juveniles against Vibrio harveyi infection. Aquaculture 16: 511-523

66. Abasali $H$, Sudagar M (2010) Immune response of common carp (Cyprinus carpio) fed with herbal immunostimulant diets. Agricultural Journal 5: 163-172.

67. Sankar G, Elavarasi A, Sakkaravarthi K, Ramamoorthy K (2011) Biochemical changes and growth performance of Black Tiger shrimp larvae after using Ricinus communis extract as a feed additive. International Journal of PharmTech Research 3: 201-208.

68. Park KH, Choi S (2014) Effects of Prunella vulgaris (Labiatae) extract with specific and non-specific immune responses in tilapia (Oreochromis niloticus) Journal of Animal Science and Technology 56: 1-7.

69. Palumbo S, Abeya C, Stelma G (1992) Aeromonas hydrophila group. Compendium of Methods for the Microbiological Examination of Food. Ed. Yvonne Salfinger and Mary Lou Tortorello 2015 American Public Health Association. Washington: Asian Paci?c American Heritage Association.

70. He S, Liu W, Zhou Z, Mao W, Ren P (2011) Evaluation of probiotic strain Bacillus subtilis C-3102 as a feed supplement for koi carp (Cyprinus carpio) Journal of Aquaculture Reserach and Development 3:S001-S005.

71. Merrifield DL, Dimitroglou A, Foey A, Davies SD, Baker R, et al. (2010) The current status and future focus of probiotic and prebiotic applications for salmonids. Aquaculture 302: 1-18.

72. Aly SM, Abdel-Galil AY, Abdel-Aziz GA, Mohamed MF (2008) Studies on Bacillus subtilis and Lactobacillus acidophilus, as potential probiotics, on the immune response and resistance of Tilapia nilotica (Oreochromis niloticus) to challenge infections. Fish and Shellfish Immunology 25: 128-136.

73. Pirarat N, Pinpimai K, Endo M, Katagiri T, Ponporpisit A, et al. (2011) Modulation of intestinal morphology and immunity in Nile tilapia (Oreochromis niloticus) by Lactobacillus rhamnosus GG. Research Veterinary Science 91: e92-e97.

74. Snieszko SF (1974) The effects of environmental stress on outbreaks of infectious diseases of fishes. Journal of Fish Biology 6: 197-208.

75. Hedrick RP (1998) Relationships of the host, pathogen, and environment: implications for disease of cultured and wild fish populations. Journal of Aquatic Animal Health 10: 107-111.

76. Toche PP (2012) Visión panorámica del sistema inmune. Revista Médica Clínica Las Condes 23: 446-457.

77. Collet B (2014) Innate immune responses of salmonid fish to viral infections. Dev Comp Immunol 43: 160-173.

78. Naylor RL, Hardy RW, Bureau DP, Chiu A, Elliott M, et al. (2009) Feeding aquaculture in an era of finite resources. Proc Natl Acad Sci USA 106: 15103-15110.

79. Lara-Flores M, Olvera-Novoa MA, Guzmán-Méndez BE, López-Madrid W (2003) Use of the bacteria Streptococcus faecium and Lactobacillus acidophilus, and the yeast Saccharomyces cerevisiae as growth promoters in Nile tilapia (Oreochromis niloticus). Aquaculture 216: 193-201.

80. Newman SG (2012) Diagnóstico de enfermedades de acuacultura es trabajo 
Citation: Huicab-Pech ZG, Landeros-Sánchez C, Castañeda-Chávez MR, Lango-Reynoso F, López-Collado CJ, et al. (2016) Current State of Bacteria Pathogenicity and their Relationship with Host and Environment in Tilapia Oreochromis niloticus. J Aquac Res Development 7: 428. doi:10.4172/2155-9546.1000428

Page 10 of 10

de detective. Global Aquaculture Advocate En Español. The Global Magazine for Farmed Seafood 15: 112.

81. Flores-Quintana C (2002) Respuestas neuroendócrinas al estrés en peces teleósteos. Revista de Ictiología 10: 57-78.

82. Ashley PJ (2007) Fish welfare: current issues in aquaculture. Applied Animal Behaviour Science 104: 199-235.

83. Collet B (2014) Innate immune responses of salmonid fish to viral infections. Dev Comp Immunol 43: 160-173.

84. Grayfer L, Jordan W, Hodgkinson JW, Miodrag BM (2014) Antimicrobial responses of teleost phagocytes and innate immune evasion strategies of intracellular bacteria. Developmental and Comparative Immunology 43: 223-242.

85. Villanueva S, Botello AV (1992) Metales pesados en la zona costera de Golfo de México y Caribe Mexicano: una revision. Revista Internacional de Contaminación Ambiental 8: 47-61.

86. Conte FS (2004) Stress and the welfare of cultured fish. Applied Anima Behaviour Science 86: 205-223

87. Penagos G, Barato $P$, Iregui C (2009) Sistema inmune y vacunación de peces. Acta Biológica Colombiana 14: 3-24

88. Sink TD, Kumaran S, Lochmann RT (2007) Development of a whole-body cortisol extraction procedure for determination of stress in golden shiners, Notemigonus crysoleucas. Fish Physiol Biochem 33: 189-193.

89. Iwama GK (1998) Stress in fish. Annals of the New York Academy of Sciences 851: 304-310.

90. Vaseeharan B, Thaya R (2014) Medical plant derivatives as immunostimulants: an alternative to chemotherapeutics and antibiotics in aquaculture. Aquaculture International 22: 1079-1091.

91. Forbes BA, Sahm DF, Weissfeld AS (2002) Bailey and Scott's diagnostic microbiology. (11thedn). St. Louis, Missouri, Mosby.

92. FAO/OMS (2009) Codex Alimentarius- Código de practicas para el pescado y productos pesqueros. (1stedn) Roma, Italia.

93. Pardilla-Mata D (2011) Estudio de protocolos de comunicación bacterianos: conjugación y quorum sensing. Laboratorio de Inteligencia Artificial, Universidad Politécnica de Madrid.

94. Sirimanapong W, Adams A, Ooi EL, Green DM, Nguyen DK, et al. (2015) The effects of feeding immunostimulant $ß$-glucan on the immune response of Pangasianodon hypophthalmus. Fish \& Shellfish Immunology 45: 357-366.

95. Doñate C, Balasch JC, Callol A, Bobe J, Tort L, et al. (2010) The effects of immunostimulation through dietary manipulation in the rainbow trout; evaluation of mucosal immunity. Marine biotechnology 12: 88-99.

96. Zaki MM, Eissa AE, Saeid S (2011) Assessment of the immune status in Nile Tilapia (Oreochromis niloticus) experimentally challenged with toxogenic/ septicemic bacteria during treatment trial with florfenicol and enrofloxacin. World Journal of Fish and Marine Sciences 3: 21-36

97. Oliveira J, Castilho F, Cunha A, Pereira MJ (2012) Bacteriophage therapy as a bacterial control strategy in aquaculture. Aquacult Int 20:879-910.

98. Rojas-Badía MM (2011) Quorum sensing en la asociación beneficiosa de las bacterias con las plantas. Revista Colombiana de Biotecnología 13: 135-143.

99. Ochieng EZ, Lalah JO, Wandiga SO (2006) Heavy metals in water and surface sediments in Winam Gulf of Lake Victoria, Kenya. Bull Environ Contam Toxicol 77: 459-468.

100. Naranjo EJ, Dirzo R, López Acosta JC, Rendón-von Osten J, Sosa-Nishizak O, et al. (2009) Impacto de los Factores Antropogénicos de Afectación Directa a las Poblaciones Silvestres de Flora y Fauna en Capital Natural de México. Estado de Conservación y Tendencias de Cambio. CONABIO, México 2 : 247-276.

101. Dixon PF, Smail DA, Algoët M, Hastings TS, Bayley A, et al. (2012) Studies on the effect of temperature and $\mathrm{pH}$ on the inactivation of fish viral and bacterial pathogens. Journal of Fish Diseases 35: 51-64.

102. Peterson BC, Booth NJ (2010) Validation of a whole-body cortisol extraction procedure for channel catfish (Ictalurus punctatus) fry. Fish Physiol Biochem 36: 661-665.

103. Peterson MS, Lowe MR (2009) Implications of cumulative impacts to estuarine and marine habitat quality for fish and invertebrate resources. Reviews in Fisheries Science 17: 505-523.

104. Bondad-Reantaso MG, Lem D, Subasinghe RP (2009) International trade in aquatic animals and aquatic animal health: What lessons have we learned so far in managing the risks? Fish Pathology 44: 107-114.

105. Burridge L, Weis JS, Cabello F, Pizarro J, Bostic K (2010) Chemical use in salmon aquaculture: $A$ review of current practices and possible environmental effects. Aquaculture 306: 7-23.

106. Barandica C, Tort B (2008) Neuroendocrinología e inmunología de la respuesta al estrés en peces. Rev. Acad. Colomb. Cienc 32: 267-284.

107. Bravo S, Dolz H, Silva MT, Lagos C, Millanao A, et al. (2005) Informe Final. Diagnostico del uso de fármacos y otros productos químicos en la acuicultura. Universidad Austral de Chile. Facultad de Pesquerías y Oceanografía, Instituto de Acuicultura. Casilla 1327: 2003-2028. 